\title{
Preview of 1994 US budget emphasizes big projects
}

\begin{abstract}
Washington. A healthy increase for the $\mathrm{Na}$ tional Science Foundation (NSF), delays in building the Superconducting Super Collider (SSC), more for technology, advanced computing and networks, a smaller space station and not enough for the $\mathrm{Na}$ tional Institutes of Health (NIH) to keep up with inflation: that is a preview of what science can expect in the federal budget that President Bill Clinton will present next month to Congress.
\end{abstract}

The economic plan that Clinton revealed last week (see page 669) also provides an unusual advance look at the 1994 budget. Of course, there are limitations: the partial budget emphasizes projects that will stimulate the economy quickly and promote the policies of the new administration, and it is silent on many aspects of the federal research enterprise.

However, the biggest difference between the 1993 stimulus package and the forthcoming 1994 budget proposal is that Congress can enact the former without hardship while the latter must be coupled with savings of equal size. This is because Clinton has declared a temporary fiscal emergency for the current year, lifting the limits on federal spending set under a five-year budget agreement reached in 1990. But those limits will be reinstated next year.

Specifically, next month's budget request is expected to contain the following:
NSF: An overall request of $\$ 3.1$ billion, an amount not much higher than NSF sought in 1993 but almost $\$ 400$ million more than it received last autumn. As with the supplementary request, next year's budget is expected to emphasize both cooperative, cross-disciplinary initiatives and grants to individual investigators.

NIH: The \$19-billion budget for the Public Health Service, of which NIH makes up slightly more than half, is expected to increase by $\$ 1.27$ billion. But Donna Shalala, the new secretary for health and human services, has said repeatedly that she will give priority to child immunization, tuberculosis, disease prevention, AIDS treatment and women's health issues. That increase also covers more money for AIDS research and a request to inherit a $\$ 200$-million allocation for breast cancer research that this year was given to the military (see Nature 359, 471; 1992), leaving NIH with barely enough to match the rate of inflation, predicted to be slightly less than 3 per cent.

- Energy: The administration will ask for $\$ 640$ million in 1994 for the SSC, \$123 million more than at present but $\$ 217$ million less than the Bush administration said last year was needed to keep it on target for completion in 1999. The president's science adviser, John Gibbons, said last week that there was "no reason why we have to find the Higgs boson by the turn of the century" and that slowing down construction will give the government time to deal with the rising cost of making the accelerator's 8,600 superconducting dipole magnets. At the same time, the budget would allow Oak Ridge (Tennessee) National Laboratory to start building a $\$ 1.7$ billion Advanced Neutron Source for materials research; scientists began designing the reactor in 1984 and have tried for the past three years to get money for construction.

NASA: After daily rumours about the fate of space station Freedom, the Clinton administration announced that the station would receive its full funding of $\$ 2.3$ billion in 1994 but that much of it would be spent on designing a smaller station capable of doing less. Although congressional supporters were

\section{Savings misnomer}

Washington. A table in the appendix to President Bill Clinton's economic plan lists four ways to reduce the federal deficit. One, entitled "Managing government for cost-effectiveness and results", includes reductions in dozens of programmes that by 1997 will amount to $\$ 35$ billion. But two research projects on that list - the Superconducting Super Collider (SSC) and the space station Freedom - will actually increase government spending by billions of dollars. So why are they on the list?

The answer reflects the speed with which things can change in Washington. In the run-up to last week's speech, when the chart was compiled, those two programmes were scheduled for cancellation. Rescued at the last minute by a president worried more about jobs than about science, the programmes appear as anomalies on a list of savings. In fact, they are the only two items lacking a minus sign to denote their contribution to reducing the deficit. J.M.

assured that no jobs would be lost, NASA officials were last week unable to say how the station will be "restructured" and what the new version will cost. Some of the money saved is to be spent on "other NASA space missions".

Commerce: Clinton wants to double by 1998 the amount of research conducted at the National Institute of Standards and Technology's own laboratories, in addition to creating more than a hundred centres across the country to help industry modernize its production lines. The plan would nearly triple NIST's civilian budget by 1997 , to $\$ 1.2$ billion. The department would continue to lead the way along an "information highway" linking businesses, schools and government agencies receiving a total of \$204 million between 1995 and 1998 to create such a network.

EPA: A new initiative in environmental engineering and technology development would receive a total of $\$ 1.85$ billion over nine years, according to the Office of Management and Budget (OMB), with a first instalment of $\$ 36$ million in 1994. Other government agencies and the private sector would be involved in this search for environmentally sound technologies and treatment techniques.

- Tax credits: The president's economic plan would make permanent a tax credit for industries that increase their research spending and would give small businesses, including high-technology startup companies, a permanent tax credit for new equipment. It would also allow investors in such companies to exclude half of their gains from stock held at least five years.

Jeffrey Mervis \& Tony Reichhardt 